\title{
Sonographic Renal Dimension in Patients with Essential Hypertension in Abubakar Tafawa Balewa University Teaching Hospital, Bauchi, Nigeria
}

1 Njoku G.A., Musa G.L., Prince O.

2 Chiegwu H.U., Ohagwu C.C.

3 Yusuf A.S., Joseph D.Z., Umar M.S., Emmanuel R. I., Sidi M., Bature S., Abba M.

4 Shem L.S.

1 Department of Radiology, Abubakar Tafawa Balewa Universty Teaching Hospital, Bauchi, Bauchi State.

2 Department of Radiography, Nnamdi Azikiwe University Akwa, Anambra State.

3 Department of Radiography, Bayero University Kano, Kano State.

4 Department of Radiography, Ahmadu Bello University Zaria, Kaduna State

\section{Abstract}

Introduction: Hypertension is one of the commonest non-communicable diseases worldwide; it is the second most common cause of end-stage renal disease.

Objective: To evaluate the renal dimensions and volume of essential hypertension patients in Abubakar Tafawa Balewa University Teaching Hospital, Bauchi and to compare the dimensions with that of apparently healthy volunteers.

Materials and Methods: A total of two hundred and eleven individuals (comprising 121 females and 90 males) with essential hypertension attending an outpatient clinic in Abubakar Tafawa Balewa University Teaching Hospital Bauchi, and an equal number of healthy volunteers (comprising of 172 females and 49 males) were studied as controls. Both the healthy volunteers and the Hypertensive patients' renal length, renal width, antero-posterior diameter, and parenchymal thickness were assessed. Statistical Package for Social Sciences (SPSS version 20.0) was used for data analysis.

Results: Study show the mean renal length for hypertensive patients to be $9.1 \pm 0.79 \mathrm{~cm}$ and $9.1 \pm 0.73 \mathrm{~cm}$, the mean renal width of $3.5 \pm 0.48 \mathrm{~cm}$ and $3.8 \pm 0.68 \mathrm{~cm}$, and mean renal volume of $87.22 \pm 19.58 \mathrm{~cm}^{3}$ and $95.08 \pm 22.93 \mathrm{~cm}^{3}$ for the right and left kidneys respectively. Results equally show statistically significant difference in anteroposterior diameter $(p<0.05)$, parenchymal thickness $(p<0.05)$ and renal volume $(p<0.05)$ between the hypertensive group and the volunteer group for both right and left kidneys.

Conclusion: This study has established baseline renal dimensions for hypertensive in our population (Bauchi Metropolis). The hypertensive subjects showed a decrease in renal anteroposterior diameter, parenchymal thickness and volume compared to control group.

Keywords: Sonography, Renal dimension, Essential hypertension, Patients.

Article received: 20.11.2019.

Article accepted: 31.01.2020.

https://doi.org/10.24141/1/6/1/5

Corresponding author:

Joseph D. Zira

E-mail: josephdlama@gmail.com

Phone: +2348130582721 


\section{Introduction}

Hypertension, especially essential hypertension, is one of the commonest non-communicable diseases worldwide [1]. It is an illness that affects people of all age groups, both sexes and at the same time cuts across all socio-economic classes. It is said to exist when the value of the systolic blood pressure is equal to or greater than $140 \mathrm{mmHg}$ and the diastolic blood pressure is equal to or greater than $90 \mathrm{mmHg}$ [2]. The high prevalence of hypertension in Nigeria which is estimated to be between $8 \%$ to $22.5 \%$ [3] has necessitated this study in order to evaluate its effect on the kidneys.

Hypertension or high blood pressure is the second leading cause of kidney failure. Over time uncontrolled hypertension can cause arteries of the kidneys to narrow, weaken or harden [4]. Hypertension remains the second most common cause of end-stage renal disease (ESRD), accounting for nearly 80,000 patients a year 2001[5]. The incidence of ESRD attributed to hypertension has increased nearly eightfold since 1981 suggesting that hypertension should be considered as important as diabetes in the current epidemic of renal disease [5]. However, it has been noted that hypertension and diabetes mellitus are the most important comorbid conditions affecting renal size [6].

Renal length is the most widely used and most easily reproducible parameter in assessing kidney size [7]. Other renal parameters have been found to be more affected by diseases such as hypertension. Renal parenchymal thickness has also been assessed and has been found to correlate well with renal function [8]. Estimation of renal size by sonography can be performed by measuring the renal length, renal volume, cortical volume or thickness. The most accurate of these is provided by the renal volume [9].

A study done by Okoye et.al [10] in South East Nigeria using ultrasound, found renal parenchymal thickness of normal individuals between 18 and 80 years to be strongly correlated to renal length, while a similar study in the United States by Cost et.al. found the renal parenchymal area measured on ultrasound to be more accurate of renal size and function.

Ultrasound scan of the kidneys is a safe and affordable method of estimating renal dimensions and offers advantages such as being non-ionising, therefore, permits frequent monitoring and follow-up of patients.
This study aimed at assessing the renal dimensions and volume of patients with essential hypertension in Bauchi metropolis and comparing the dimensions and volume with those of the healthy volunteers. These dimensions include renal length, renal width, anteriorposterior diameter, and parenchymal thickness.

\section{Materials and Methods}

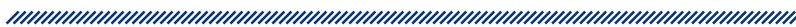

This study was carried out at the Radiology Department of the Abubakar Tafawa Balewa University Hospital, Bauchi, Bauchi State, from April 2017 to December 2017. Four hundred and twenty-two adults between the ages of 18 to 80 years, consisting of 211 essential hypertension patients and the equal number of normotensive individuals, were recruited for this study. The essential hypertension patients were recruited from the outpatient clinic where they were being treated, while the healthy volunteers were recruited from the general outpatient department.

Pregnant women, patients with kidney duplication, diabetic patients, patients with renal masses, hydronephrosis, and renal malformation, were excluded. All individuals were from the Bauchi Metropolis.

A written informed consent was obtained from each participant. Blood pressure was measured using the Welch Align manual blood pressure cuff with a mercury device, and a 3M classic stethoscope. Biometric parameters including height and weight were taken, and Body Mass Index (BMI) was calculated.

All ultrasound scans were done using a single real-time ultrasound scanner with a 3.5- $\mathrm{MHz}$ curvilinear transducer (Aloka, made in Germany, model IP-1233 EV) by the sonographer who was well-qualified and licenced to practice radiography in Nigeria. Detailed update training was conducted to ensure accuracy of measurement and a follow-up was done during ultrasound measurement to ensure accuracy of measurement. Each individual was examined sonographically by positioning them in the supine position with the abdomen properly exposed from the upper abdomen to the pubis symphysis. The kidney measurements were taken in the longitudinal as well as the transverse plane at the level of the hilum on a static image. Longitudinal and 
transverse scans of the kidneys were obtained in the supine, lateral decubitus, and prone positions. Renal dimensions including length, width, anteroposterior diameter, as well as renal parenchymal thickness, were assessed.

For renal dimensions, images were acquired in the longitudinal plane with both renal poles clearly demonstrated, and in the transverse plane at the level of the hilum. Using electronic callipers, the renal length (L) was measured from the outer edge of the upper pole to the outer edge of the lower pole, and the renal width (W) was measured from the mid portion from the outer anterior wall (cortex) to the outer posterior wall (cortex) perpendicular to the renal length. The anteroposterior diameter was measured with the transducer at the transverse plane, while the renal parenchymal thickness was obtained from the outer renal cortex to the outer margin of the sinus echoes. Renal volume was calculated using the ellipsoid volume $\left(\mathrm{cm}^{3}\right)$ formula $=$ length $(\mathrm{cm}) \times$ width $(\mathrm{cm}) \times$ anteroposterior diameter $(\mathrm{cm}) \times 0.523$. All measurements were done by one observer, the values were taken three times and the average value was taken to reduce intra-observer errors. See Figure 1. (a, b and c).

Data analysis was done using the Statistical Package for Social Sciences (SPSS) version 20.0 (SPSS Incorporated, Chicago Illionis). The mean and standard deviation were used as measures of the central tendency. Test for normality was conducted using the Kolmogorov-Smirnov test and the result showed the data to be normally distributed. Independent Samples t-Test was used to compare the mean renal dimensions of the healthy volunteers against the mean renal dimensions of patients with essential hypertension. Statistical significance was set at $p<0.05$.

\section{Results}

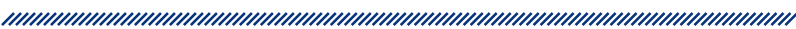

Two hundred and eleven patients with confirmed essential hypertension and two hundred and eleven healthy volunteers participated in this study. The mean age of hypertensive patients is $49 \pm 13.87$ years and that of healthy volunteers is $35.21 \pm 9.76$ years. There is a statistically significant difference in height and weight between the essential hypertension patients and the healthy volunteers. Among the hypertensive individuals there were 90 males and 121 females representing $43 \%$ and $57 \%$ respectively, and the healthy volunteers there were 49 (21.9\%) males and 172 (78.1\%) females.

Table 2 shows the mean renal dimensions and volume for apparently healthy volunteers and individuals with essential hypertension. The mean renal length for the apparently healthy volunteers is $9.8 \pm 0.92 \mathrm{~cm}$ and 10.3 $\pm 6.26 \mathrm{~cm}$ for the right and left kidney respectively, and $3.9 \pm 0.55 \mathrm{~cm}$ and $4.1 \pm 054 \mathrm{~cm}$ for the right and left mean renal width respectively. Also, the right and left kidneys of the volunteers have mean anteroposterior

\begin{tabular}{|c|c|c|}
\hline \multicolumn{4}{|c|}{ Table 1. Socio-demographic and laboratory parameters of the patients with hypertension and } \\
the healthy volunteers
\end{tabular}




\begin{tabular}{|c|c|c|}
\hline \multicolumn{2}{|c|}{ Table 2. Renal sizes and parenchymal thickness } \\
\hline \multicolumn{1}{|c|}{} & Volunteers & Hypertensive patients \\
\hline Right Renal Length $(\mathrm{cm})$ & $9.8 \pm 0.92$ & $9.1 \pm 0.79$ \\
Left Renal Length $(\mathrm{cm})$ & $10.3 \pm 6.26$ & $9.1 \pm 0.73$ \\
\hline Right Renal Width $(\mathrm{cm})$ & $3.9 \pm 0.55$ & $3.5 \pm 0.48$ \\
Left Renal Width $(\mathrm{cm})$ & $4.1 \pm 0.54$ & $3.8 \pm 0.68$ \\
\hline Right AP diameter $(\mathrm{cm})$ & $5.6 \pm 3.40$ & $5.1 \pm 0.33$ \\
Left AP diameter $(\mathrm{cm})$ & $5.4 \pm 0.69$ & $5.3 \pm 0.34$ \\
\hline Right Renal Parenchymal thickness $(\mathrm{cm})$ & $1.6 \pm 0.33$ & $1.4 \pm 0.27$ \\
Left Renal Parenchymal thickness $(\mathrm{cm})$ & $1.7 \pm 0.41$ & $1.4 \pm 0.30$ \\
Right Renal Volume $\left(\mathrm{cm}^{3}\right)$ & $118.42 \pm 16.04$ & $87.22 \pm 19.58$ \\
Left Renal Volume $\left(\mathrm{cm}^{3}\right)$ & $122.49 \pm 75.95$ & $122.49 \pm 75.95$ \\
\hline
\end{tabular}

a)

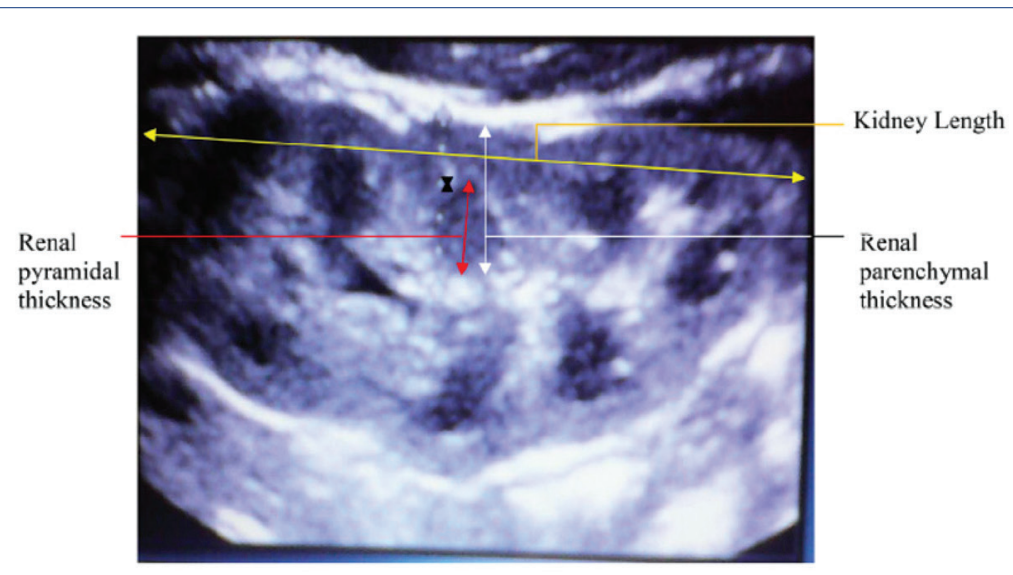

b)

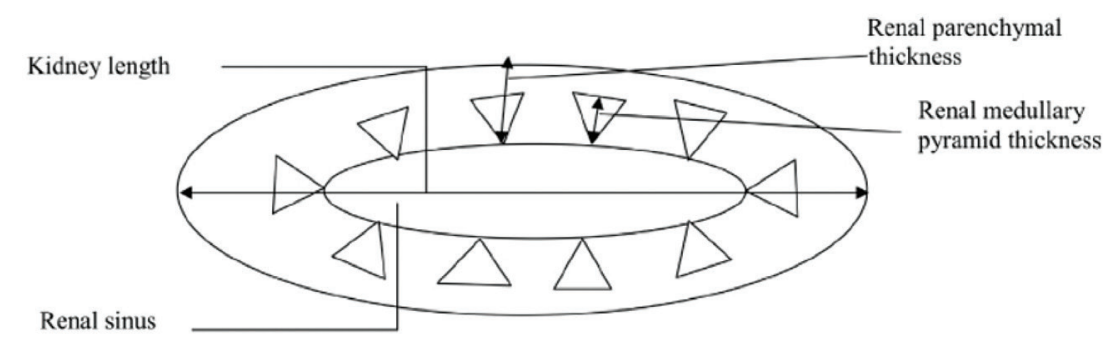

Figure 1. Images of ultrasound measurement of renal length, renal parenchymal thickness and renal pyramidal thickness were adopted from Campbell-Walsh Urology $10^{\text {th }}$ Edition

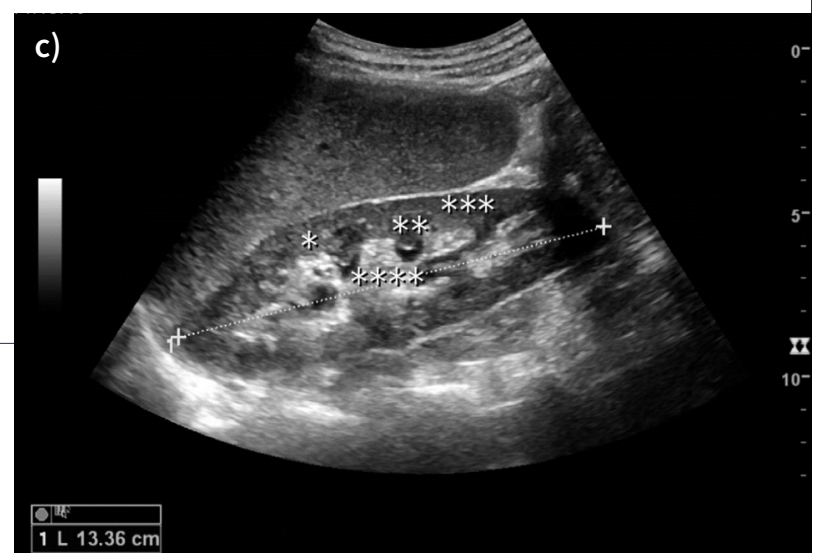


diameter of $5.6 \pm 3.40 \mathrm{~cm}$ and $5.4 \pm 0.69 \mathrm{~cm}$ and mean parenchymal thickness of $1.6 \pm 0.33 \mathrm{~cm}$ and $1.7 \pm 0.41$ $\mathrm{cm}$ respectively.

The mean renal length for patients with essential hypertension is $9.1 \pm 0.79 \mathrm{~cm}$ and $9.1 \pm 0.73 \mathrm{~cm}$ for right and left kidney respectively, while mean renal width for right and left kidneys is $3.5 \pm 0.48 \mathrm{~cm}$ and $3.8 \pm 0.68$ $\mathrm{cm}$ respectively. Also, the right and left kidneys respectively have a mean anteroposterior diameter of $5.1 \pm$ $0.33 \mathrm{~cm}$ and $5.3 \pm 0.34 \mathrm{~cm}$ and parenchymal thickness of $1.4 \pm 0.27 \mathrm{~cm}$ and $1.4 \pm 0.30 \mathrm{~cm}$ respectively. The mean renal volume for the volunteer group is $118.42 \pm 16.04$ $\mathrm{cm}^{3}$ and $122.49 \pm 75.95 \mathrm{~cm}^{3}$, the mean renal volume for hypertensive patients for right and left kidneys is 87.22 $\pm 19.58 \mathrm{~cm}^{3}$ and $95.08 \pm 22.93 \mathrm{~cm}^{3}$ respectively.

A comparison of kidney size, parenchymal thickness and a mean renal volume between the volunteer group and hypertensive patients, the Student's t-Test indicated a statistically significant difference in the anteroposterior diameter $\left(0.000^{\star}\right)$, parenchymal thickness $\left(0.000^{\star}\right)$ and renal volume $\left(0.020^{\star}\right)$ between the hypertensive group and the volunteer group for both right and left kidneys $(p<0.05)$. However, no statistically significant difference was seen in the renal width between the two groups for the right and left kidneys ( $p>0.05)$. Similarly, there was a statistically significant difference in the lengths of the right kidney between the patients with essential hypertension and the volunteer group ( $p$ $<0.05$ ). There was no difference in the length of the left kidney between the two groups $(p>0.05)$. All these data are shown in Table 3.

\section{Discussion}

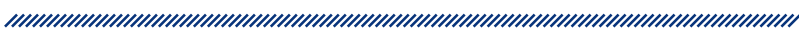

In this study, the mean renal length for the volunteer group which is $9.8 \pm 0.92 \mathrm{~cm}$ and $10.3 \pm 6.26 \mathrm{~cm}$ for the right and left kidneys respectively, is similar to that of Okoye et al. [10] whose findings showed the mean renal length of $10.3 \mathrm{~cm}$ and $10.4 \mathrm{~cm}$ for the right and left kidneys respectively. Also, the findings of this study are similar to that of Neils-Peter et al. [11] in a Pakistani population, where the mean kidney lengths were $9.85 \mathrm{~cm}$ for the right kidney and $10.0 \mathrm{~cm}$ for the left, and the mean renal width was $4.61 \mathrm{~cm}$. However, the findings from this study are not similar to the results of a study which was conducted in North West Nigeria by Sadisu et al. [12] to establish some normal preliminary renal dimension data for their population. The results of their study showed

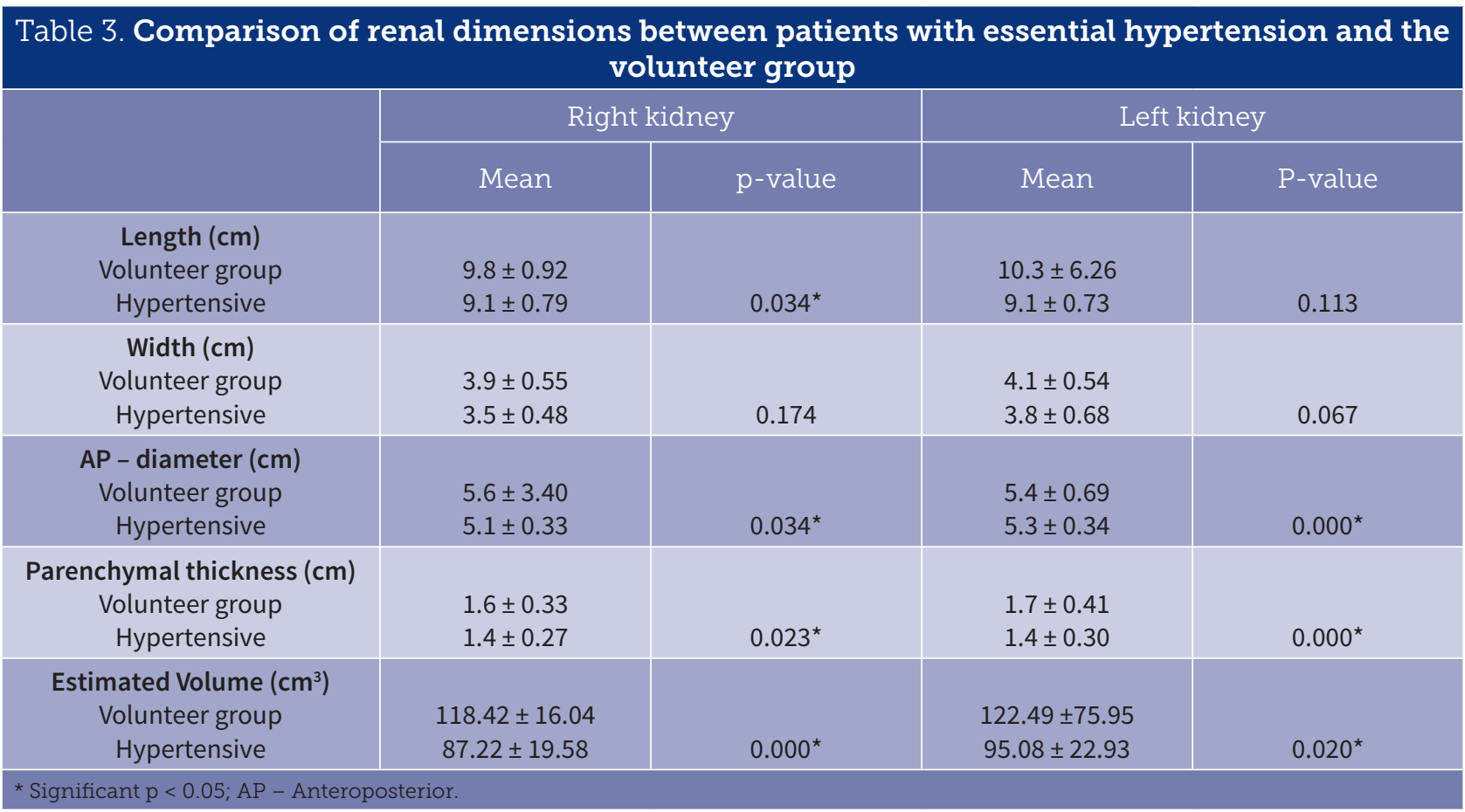


the mean kidney length to be $11.3 \mathrm{~cm}$ and $11.6 \mathrm{~cm}$ for the right and left kidneys respectively, and the renal volume was $109.6 \mathrm{~cm} 3$ for the right kidney and $119.7 \mathrm{~cm} 3$ for the left kidney. Findings from this study also differ in terms of renal length, but are similar in anteroposterior diameter and parenchymal thickness with the results of a study conducted in South South Nigeria by Okeke et al.[13] which revealed the mean renal length of $10.4 \mathrm{~cm}$ and $10.8 \mathrm{~cm}$ for the right and left kidneys respectively, a mean anteroposterior diameter of $5.6 \pm 3.40 \mathrm{~cm}$ and $5.4 \pm$ $0.69 \mathrm{~cm}$ and parenchymal thickness of $1.6 \pm 0.33 \mathrm{~cm}$ and $1.7 \pm 0.41 \mathrm{~cm}$ for the right and left kidneys respectively for South South Nigerian population. The results of this study show a significant decrease in anteroposterior diameter, parenchymal thickness and renal volume of the hypertensive group when compared with volunteers for both right and left kidneys, however, no statistically significant difference was seen in renal width between the two groups for the right and left kidney ( $p>0.05$ ). Also, the mean renal length in hypertensive patients showed a significant decrease in the right kidney compared to that of the volunteers $(p<0.05)$ while the measurements on the left kidney showed no statistically significant difference $(p>0.05)$. The findings of this study disagree with the findings of Egberongbe et al. [14] which reported no significant difference between the mean renal volume of the hypertensive group and the control group. The findings in this study are also similar to the findings of a study that was carried out in Karachi, Pakistan, on the renal dimensions of adults, including hypertensive patients, which showed significant difference in renal dimensions between the hypertensive and the control group [15].

\section{Conclusion}

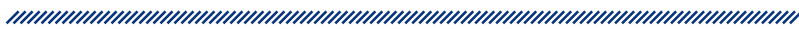

This study established the baseline values of renal dimensions and volume among healthy subjects and hypertensive patients in our environment. The hypertensive subjects showed a decrease in renal anteroposterior diameter, parenchymal thickness and volume compared to the control group.

\section{Financial support and sponsorship}

Nil.

\section{Conflicts of interest}

There are no conflicts of interest. 


\section{References}

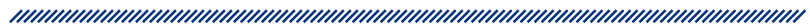

1. Singh GR, and Hoy WE. Kidney volume, blood pressure, and albuminuria: findings in an Australian aboriginal community. American journal of kidney diseases. 2004;1;43(2):254-9.

2. Ekore RI, Ajayi IO, and Arije A. Case finding for hypertension in young adult patients attending a missionary hospital in Nigeria. African health sciences. 2009;9(3): 22-26.

3. Akinlua, JT, Meakin R, Umar AM, and Freemantle N. Current Prevalence Pattern of Hypertension in Nigeria: A Systematic Review. Public Library of Science. 2015;10(10): 21-24.

4. Tahir K, Muneeb, M. and Khalid S. Management of Hypertensive nephropathy. Journal of Biomedical Sciences. 2010;2 (4): 295-301.

5. Richard J.J., Segal, M.S., Srinivas, T., Ejaz, A., Mu, W., Roncal, C., Sánchez-Lozada, L.G.,Gersch, M., Rodriguez-Iturbe, B., Kang, D.H. and Acosta, J.H. Essential hypertension, progressive renal disease, and uric acid: a pathogenetic link?. Journal of the American Society of Nephrology. 2005;16(7):19091919.

6. Hiraoka M, Hori C, Tsuchida S, Tsukahara H. and Sudo M. Ultrasonographic findings of acute tubulointerstitial nephritis. American journal of nephrology. 1996 16(2): 154- 158.

7. Nwafor NN, Adeyekun AA, Adenike OA. Sonographic evaluation of renal parameters in individuals with essential hypertension and correlation with normotensives. Nigerian journal of clinical practice. 2018;21(5):578-84.

8. Cost GA, Merguerian PA, Cheerasarn SP, Shortliffe LM. Sonographic renal parenchymal and pelvicaliceal are- as: New quantitative parameters for renal sonographic followup. Journal of Urology. 1996;156:725-9.

9. Cheong B, Muthupillai R, Rubin MF, Flamm SD. Normal values for renal length and volume as measured by magnetic resonance imaging. Clinical Journal of the American Society of Nephrology, 2007;2: 38-45.

10. Okoye IJ, Agwu KK, Eze CU. Relationship between sonographic renal length and renal parenchymal thickness in normal adult Southeast Nigerians. West African Journal of Medicine and medical sciences. 2006;25:231-4.

11. Neils-Peter B, Abbas F, Biyabani SR, Javed Q, Talati J, Afzal M, Rizvi I. Ultrasonographic renal size in individuals without known renal disease. Journal of the Pakistan Medical Association. 2000;96(1):12.

12. Sadisu MM., Daniel O. and Adamu B. Sonographic measurement of renal dimensions of adults in northwestern Nigeria: a preliminary report. Sub-Saharan African Journal of Medicine. 2015;2(3):123.

13. Okeke OC, Ikubor JE, Okeke CE, Nwankwo NC and Awosanya GG. Ultrasound evaluation of renal length of healthy adults in University of Port Harcourt Teaching Hospital, Nigeria. Annals of Bioanthropology. 2016; 4(1): 47.

14. Egberongbe AA, Adetiloye VA, Adeyinka AO, Afolabi OT, Akintomide AO, and Ayoola OO. Evaluation of renal volume by ultrasonography in patients with essential hypertension in Ile-Ife, south western Nigeria. Libyan Journal of Medicine. 2010;5:1-5.

15. Zeb S, Mirza W, Sayani R, Sheikh A, Yazdani I. and Ather Hussain S. Sonographic measurement of renal dimensions in adults and its correlates. International Journal of Collaborative Research on Internal Medicine. 2012;4: 26-31. 


\section{SONOGRAFSKI PRIKAZ DIMENZIJA BUBREGA U BOLESNIKA S ESENCIJALNOM HIPERTENZIJOM U SVEUČILIŠNOJ BOLNICI ABUBAKAR TAFAWA BALEWA U GRADU BAUCHI U NIGERIJI}

\section{Sažetak}

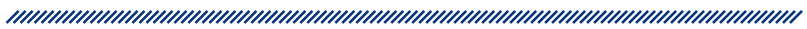

Uvod: Hipertenzija je jedna od najčešćih nezaraznih bolesti u svijetu; drugi je najčešći uzrok završnog stadija bubrežne bolesti.

Cilj: Procijeniti dimenzije bubrega i bubrežni volumen kod hipertenzivnih bolesnika u Sveučilišnoj bolnici Abubakar Tafawa Balewa u gradu Bauchi i usporediti ih s dimenzijama kod naizgled zdravih ispitanika koji su se dobrovoljno javili za sudjelovanje u istraživanju.

Materijali i metode: Uzorak se sastojao od dvjesto jedanaest ispitanika (121 žena i 90 muškaraca) koji boluju od esencijalne hipertenzije i na ambulantnom su liječenju u Sveučilišnoj bolnici Abubakar Tafawa Balewa u gradu Bauchi i jednakog broja zdravih ispitanika (172 žene i 49 muškaraca), koji su bili kontrolna skupina. Proučavana je duljina i širina bubrega, anteroposteriorni promjer i debljina parenhima kod ispitanika s hipertenzijom i kod zdravih ispitanika. Za analizu podataka primijenjen je statistički paket za društvene znanosti (SPSS verzija 20.0).

Rezultati: Studija pokazuje da je prosječna dužina bubrega kod hipertenzivnih bolesnika $9,1 \pm 0,79 \mathrm{~cm}$ i $9,1 \pm 0,73 \mathrm{~cm}$, prosječna bubrežna širina $3,5 \pm 0,48 \mathrm{~cm}$ i $3,8 \pm 0,68 \mathrm{~cm}$, a prosječni bubrežni volumen $87,22 \pm 19,58 \mathrm{~cm}^{3}$ i 95,08 $\pm 22,93 \mathrm{~cm}^{3}$ za desni i lijevi bubreg pojedinačno. Rezultati također pokazuju statistički značajnu razliku u anteroposteriornom promjeru $(p<0,05)$, debljini parenhima $(p<0,05)$ i bubrežnom volumenu $(p<0,05)$ između hipertenzivne skupine i kontrolne skupine za desni i lijevi bubreg.
Zaključak: Ovom su studijom utvrđene osnovne bubrežne dimenzije kod hipertenzivnih bolesnika u populaciji grada Bauchi, glavnog grada Savezne države Bauchi u Nigeriji. Kod ispitanika koji boluju od hipertenzije ustanovljeno je smanjenje anteroposteriornog promjera bubrega, debljine parenhima i bubrežnog volumena u usporedbi s kontrolnom skupinom

Ključne riječi: sonografija, bubrežni dimenzija, esencijalna hipertenzija, pacijenti, dimenzija 